\title{
Strategy for Tourism Development in Ex-Tin Mining, Lake Pongkar Tanjung Balai Karimun, Riau Islands, Indonesia
}

\author{
T. Putri Tiara \\ Department of Geography \\ University of Indonesia Education \\ Bandung, Indonesia \\ Coresponding email: tiara.tengkuputri@yahoo.com \\ Darsiharjo \\ Department of Geography \\ University of Indonesia Education \\ Bandung, Indonesia
}

\begin{abstract}
Government aggressively explores mining potential because of the limited ability of the state to earn revenue from other sectors. The mining activities have been taking place in Riau Islands since many years ago. Tanjung Balai Karimun is one of the lead mining regions in Riau Islands that would have a negative impact as a result of tin mining The main problem raises at the post-mining area is environmental change, a decrease in soil physical, changes in land topography and much more. Postmining activities carried out by a particular company and the community on the island resulted a gaping hole which filled with rainwater that eventually becomes a lake which is not used optimally. In this case, the Lake Pongkar has a potential to be utilized as a tourist attraction. This study aim is to make a development strategy of Lake Pongkar as a tourist attraction that can be use by the government or anyone who want to utilize excavated tin mines. Data analysis has used SWOT analysis to assess all the strategies elaborated so far to develop The lake Pongkar as a tourist attraction. The result of the study showed that Pongkar Lake can be developed as a sustainable tourism with internal and external factors owned
\end{abstract}

Keywords-Tourism development strategy, resource management, lake tourism, ex-tin mining

\section{INTRODUCTION}

Tourism has become an important economic activity in society. Well-planned sustainable tourism programs provide opportunities for the visitor to experience natural areas and human communities. Sustainable tourism is a response from the academia, development actors and tourist to the importance of maintaining earth as one of the planets where the human can live (Maryani, 2015).

Sustainable tourism development meets the needs of present tourists and host regions while protecting and enhancing opportunities for the future. It is envisaged as leading to management of all resources in such a way that economic, social and aesthetic needs can be fulfilled while maintaining cultural integrity, essential ecological processes, biological diversity and life support systems (Commonwealth of Australia, 2004). The aim of sustainable tourism is to ensure that development brings a positive experience for local people, tourism companies and the tourists themselves (Yazdi, 2012). Sustainable tourism has three key components, sometimes referred to as the "triple bottom line":

- Environmentally, sustainable tourism has a low impact on natural resources, particularly in protected areas. It minimizes damage to the environment (flora, fauna, habitats, water, living marine resources, energy use, contamination, etc.) and ideally tries to benefit the environment.

- Socially and culturally, it does not harm the social structure or culture of the community where it is located. Instead, it respects local cultures and traditions. It involves stakeholders (individuals, communities, tour operators, government institutions) in all phases of planning, development, and monitoring, and educates stakeholders about their roles.

- Economically, it contributes to the economic well-being of the community, generating sustainable and equitable income for local communities and as many other stakeholders as possible. It benefits owners, employees and neighbors. It does not simply begin and then rapidly die because of poor business practices (SNOAA, 2004).

Countries and regions where the economy is driven by the tourism industry have become increasingly concerned with the environmental, as well as the socio-cultural problems associated with unsustainable tourism. As a result, there is now increasing agreement on the need to promote sustainable tourism development to minimize its environmental impact and to maximize socio-economic overall benefits at tourist destinations (Neto, 2003).

Indonesia is the world's second-biggest tin producer after China with nearly 100,000 tons refined tin exported annually. Indonesia's tin reserves amounted to $8.1 \%$ of the world's tin reserves which includes the islands of Karimun, Kundur, Singkep, Bangka Belitung, Bangkinang, Anambas islands, 


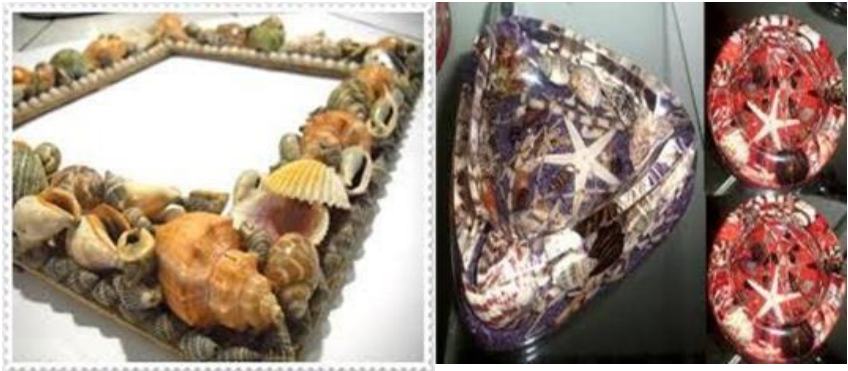

Fig. 8. The Suvenirs (www.Google.com)

\section{- Campground}

The scenery around Lake Pongkar are still beautiful and surrounded by forest Jantan Mountain area is a potential that can be developed for camp activities. Pongkar lake region can be divided for multiple activities such as camp activities. Figure 9 is a picture Pongkar lake and surrounding scenery that can be utilized.

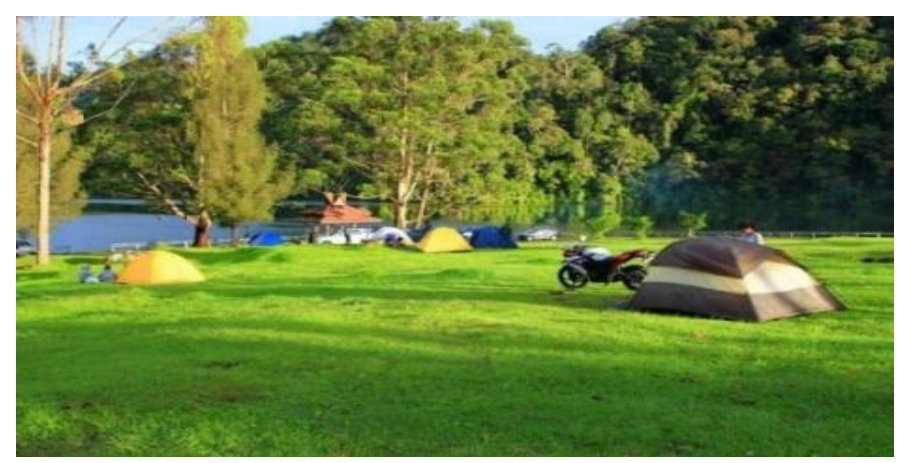

Fig. 9 (Private Documentation 2013)

All activities and facilities tourism above can be applied in lake pongkar as a development to be a tourist attraction. Transportation structures allow tourists coming either through air, sea and land and more reconstructions of internal roads facilitate interaction of various operators involved in tourism industry (Vladi, 2014). So that accessibility into the lake pongkar needs to be improved to support lake pongkar be a tourist attraction. Various transportation started from mainland transport, the sea, and air slowly began to build to provide access to tourists who come from outside the Karimun Island.

\section{SWOT Analysis}

SWOT Analysis is based on logic to maximize strength and opportunities, but simultaneously to minimize Weakness and Threats. Analysis of internal and external factors used to identify strengths and weaknesses, and is able to minimize them and at the same time maximizing the power. The same also applies to the threats and opportunities, at which time the threat can be minimized, the chance that there would be enlarged. Table II is an exposure of Strength, weakness, opportunity and threat The Lake Pongkar as a tourist attraction.

TABLE II. SWOT MATRIX (MAIN FACTORS INFLUENCING THE LAKE PONGKAR AS A TOURIST ATTRACTION THE MATRIX OF STRENGTHS, WEAKNESSES, OPPORTUNITIES AND THREATS)

\begin{tabular}{|c|c|}
\hline Strength (S) & Weakness (W) \\
\hline $\begin{array}{l}\text { 1. The Lake Pongkar has a } \\
\text { beautiful view. } \\
\text { 2. Specific Culinary Typical } \\
\text { Malay. } \\
\text { 3. There are a variety of tourist } \\
\text { events that can be held. } \\
\text { 4. The Lake Pongkar is the one } \\
\text { and only eco-friendly } \\
\text { tourism in Tanjung Balai } \\
\text { Karimun. } \\
\text { 5. Low-Cost tourism. } \\
\text { 6. Good Accessibility } \\
\text { 7. The Society around Lake } \\
\text { Pongkar is friendly, } \\
\text { participatory and very open } \\
\text { to tourism development. } \\
\text { 8. The availability of clean } \\
\text { water with sufficient. } \\
\text { quantities at The lake } \\
\text { Pongkar. }\end{array}$ & $\begin{array}{l}\text { 1. The number of public } \\
\text { transport still limited. } \\
\text { 2. The Lake Pongkar is not } \\
\text { passed directly by public } \\
\text { transport so it is quite } \\
\text { difficult for the visitors to go } \\
\text { there. } \\
\text { 3. The limited funds for } \\
\text { tourism development. } \\
\text { 4. Media that used to } \\
\text { promotion of tourism has } \\
\text { not been so supportive. } \\
\text { 5. Human resources in the field } \\
\text { of tourism have been } \\
\text { inadequate. } \\
\text { 6. Facilities have not been } \\
\text { built. }\end{array}$ \\
\hline Opportunity (O) & Threats (T) \\
\hline $\begin{array}{l}\text { 1. Tanjung Balai Karimun is } \\
\text { located on the path to } \\
\text { international trade. } \\
\text { 2. The potential of the Lake } \\
\text { Pongkar is not used } \\
\text { optimally. } \\
\text { 3. The distance is quite far } \\
\text { from the city center so that } \\
\text { the air is not polluted. } \\
\text { 4. The network of electricity } \\
\text { and mobile phones are } \\
\text { adequate. } \\
\text { 5. The situation and conditions } \\
\text { are quiet and comfortable } \\
\text { allowing tourists to enjoy } \\
\text { the attractions there. } \\
\text { 6. Surrounding communities } \\
\text { have a desire to develop and } \\
\text { manage the Lake Pongkar as } \\
\text { a tourist attraction In } \\
\text { Tanjung Balai Karimun. }\end{array}$ & $\begin{array}{l}\text { 1. The existence of a tourist } \\
\text { attraction which has some } \\
\text { similarities with the power } \\
\text { to Visit Lake Pongkar travel. } \\
\text { 2. There are no investors who } \\
\text { want to invest in tourism in } \\
\text { Tanjung Balai Karimun. } \\
\text { 3. Effect of the cultural life and } \\
\text { local customs. } \\
\text { 4. The number of tourists who } \\
\text { fluctuate. }\end{array}$ \\
\hline
\end{tabular}

As it has been shown in table II, 8 internal strengths versus 6 internal weaknesses, and 6 external opportunities versus 4 external threats have been identified and studied. Thus, a total of 14 strengths and opportunities as the advantages, and 10 weaknesses and threats as the limitations and constraints facing the development of tourism in this region can be identified. The SWOT matrix of strategies of development in terms of opportunities, threats, strengths and weaknesses are presented below based on 4 strategies, i.e. SO, ST, WO and WT.

- Competitive Strategies (SO) competitive strategies that focus on internal strengths and external opportunities, the following strategies to exploit existing advantages to develop Pongkar Lake as a tourist attraction are :

a) Develop tourist attraction lake pongkar in a sustainable way by the procurement of facilities and infrastructure supporting. 
b) Use public participation as a guide in various tourist activities.

c) Promote by the more effective and efficient media.

d) Supporting the private sector to invest in tourism industry in Tanjung Balai Karimun.

- Strategies of variety (ST), In diversification strategies that focus on the internal strengths and external threats, the following strategies are presented to provide some requirements of Lake Pongkar in order to meet the threat:

a) Maintain religious values and local culture not to eroded by means of slipped various tourism activity related to value and local knowledge in each tourist attraction.

b) Activate various tourist activities which is not harming the environment.

c) Determining the optimal population density in visiting this area in order to protect environmental degradation.

- Revising strategies (WO), In the revising strategies, we try to take advantage of external opportunities to address weaknesses facing this tourist region

a) Increase of development and maintenance of facilities and infrastructure supporting tourist attraction lake pongkar.

b) Tourism disseminating information to the media that is more efficient.

c) The increase participation of society in developing transportation local of the local community that can be used by tourists.

- Defensive strategies (WT), In this strategy, in addition to emphasis on removing the vulnerability of the studied area, the following strategies are provided :

a) To increase the number of public transportation that passes through lake pongkar.

b) use local houses as homestay while maintaining the comfortable of tourists.

c) Teaching the societies around Lake Pongkar how to deal with tourists.

d) Improving the quantity and the quality of human resources who excels in tourism.

e) Community involvement in the development of tourism from the design until the stages of supervision.

\section{CONCLUSIONS AND SUGGESTIONS}

I consider that for The Lake Pongkar this solution resides in establish a long-term strategy for the development of sustainable tourism with internal and external factors owned, involving all the stakeholders and planning concrete steps to finally achieve a good position as a tourism destination. Weakness and threats can be minimized with strengths and opportunities owned. However, in the development of lake pongkar become a tourist attraction requires serious effort considering lake pongkar has not yet harnessed as a tourist attraction. Participation of society around the lake is needed to improve the welfare of locals and keep the local wisdom values. There have been six important strategies to develop The Lake Pongkar as a tourist attraction are as follows:

- Establish cooperation with open up the opportunity to investors further developed the tourist attraction.

- Improve the quantity and the quality of human resources superior in tourism.

- Develop the potential of lake pongkar as a tourist attraction by developing various tourist activities that can be conducted at lake pongkar.

- The provision of facilities and infrastructure that support tourism lake pongkar as a tourist attraction and increase the number of transportation immediate past the tourist attraction.

- Involving community participation in the development of lake pongkar as a tourist attraction by teaching them how to deal with tourists.

- Media promotion which is used should more effectively and efficiently.

\section{REFERENCES}

[1] Maryani, 2015, "Kecerdasan Ruang dalam Pembelajaran Geografi”, Paper in national seminar with theme "Peringatan Hari Bumi untuk Meningkatkan Kecerdasan Ruang”, 22 April 2015, Bandung.

[2] Commonwealth of Australia, 2004, "Steps to Sustainable Tourism. Planning a Sustainable Future for Tourism, Heritage and The Environment", https://www.environment.gov.au/resource/stepssustainable-tourism

[3] Yazdi, S.K, 2012, "Sustainable Tourism", American International Journal of Social Science, vol. 1 (1), 2012

[4] Sanctuaries National Oceanic and Atmospheric Administration, 2004 "Sustainable Tourism Concept", Edition 1, Department of Commerce, U.K, https://www.environment.gov.au/resource/steps-sustainabletourism.

[5] Neto, F, 2003, “A New Approach to Sustainable Tourism Development: Moving Beyond Environmental Protection”, Discussion Paper No. 29, United States.

[6] Department of Energy and Mineral Resources, 2014, "Koordinasi dan Supervisi atas Pengelolaan Pertambangan di Kepulauan Riau", http://www.minerba.esdm.go.id/library/content/file/28935Paparan\%20Korsup\%20Kepri/2ddef6aa0bfab7f68f243c1bbda19d25201 4-03-25-14-41-01.pdf.

[7] Department of Culture and Tourism of Indonesia Republic, 2011, "Strategi Pengembangan Daya Tarik Wisata Danau Semarang", https://menyelamatkandanaulimboto.files.wordpress.com/2011/10/2 dukungan-kemenbudpar-dalam-pengelolaan-danau.pdf.

[8] Carbone, G. and Eugenio Y, 2005, "Making Tourism More Sustainable A guide for policy makers. United Nation Environtment Programme and World Tourism Organization", http://www.unep.fr/shared /publications/pdf/DTIx0592xPA-TourismPolicyEN.pdf

[9] Vladi, E, 2014, "Tourism Development Strategies, SWOT Analysis and Improvement of Albania's Image", European Journal of Sustainable Development, vol. 3 (1), pp. 167-178. 